\title{
The role of pyruvate carboxylase in insulin secretion and proliferation in rat pancreatic beta cells
}

\author{
J. Xu • J. Han • Y. S. Long • P. N. Epstein • Y. Q. Liu
}

Received: 23 June 2008 / Accepted: 16 July 2008 / Published online: 4 September 2008

(C) Springer-Verlag 2008

\begin{abstract}
Aims/hypothesis Pyruvate carboxylase (PC) or pyruvate dehydrogenase (PDH) is required to transfer carbons from pyruvate into the Krebs cycle. PC activity is preserved in the islets of obese animals, but it is reduced in the islets of animal models of type 2 diabetes, suggesting that PC is important in beta cell adaptation to insulin resistance and that $\mathrm{PC}$ reduction may lead to beta cell failure.

Methods To confirm the significance of PC, we first lowered activity using $P c$ (now known as $P c x$ ) small interfering RNA (siRNA) in INS-1 cells and in dispersed rat islet cells. Second, we overexpressed $P C$ in INS-1 cells, and third, we inhibited PDH by overexpressing the gene encoding pyruvate dehydrogenase kinase 4 (Pdk4) in INS-1 cells.

Results Treatment of INS-1 cells or dispersed rat islet cells with $P c$ siRNA resulted in a significant reduction in insulin
\end{abstract}

Electronic supplementary material The online version of this article (doi:10.1007/s00125-008-1130-9) contains supplementary material, which is available to authorised users.

J. Xu and J. Han contributed equally to this study.

J. Xu · J. Han · Y. S. Long · P. N. Epstein · Y. Q. Liu

Kosair Children's Hospital Research Institute,

Department of Pediatrics,

University of Louisville School of Medicine,

Louisville, KY, USA

J. Han • Y. Q. Liu $(\bowtie)$

The Research Institute for Children,

Children's Hospital,

200 Henry Clay Avenue,

New Orleans, LA 70118, USA

e-mail: yliu@chnola-research.org

P. N. Epstein

Department of Pharmacology and Toxicology,

University of Louisville School of Medicine,

Louisville, KY, USA

Y. Q. Liu

Department of Pediatrics, LSUHSC,

New Orleans, LA, USA secretion in both cell types and reduced proliferation in INS-1 cells. This treatment also reduced the content of oxaloacetate, malate and ATP, as well as the NADPH: $\mathrm{NADP}^{+}$ratio and activity of the pyruvate-malate shuttle. Overexpression of $P C$ in INS-1 cells led to an elevation of insulin secretion and cell proliferation, whereas inhibition of PDH activity by overexpressing Pdk4 in INS-1 cells did not reduce insulin secretion.

Conclusions/interpretation Our findings indicate that the PC pathway in beta cells might play a key role in pyruvate metabolism, insulin secretion and cell proliferation.

Keywords INS- 1 cell $\cdot$ Insulin secretion .

Islets of Langerhans $\cdot$ Pyruvate carboxylase $\cdot$ Pyruvate

dehydrogenase $\cdot$ Pyruvate-malate shuttle

$\begin{array}{ll}\text { Abbreviations } \\ \text { GSIS } & \text { glucose-stimulated insulin secretion } \\ \text { NMR } & \text { nuclear magnetic resonance } \\ \text { PC } & \text { pyruvate carboxylase } \\ \text { PDH } & \text { pyruvate dehydrogenase } \\ \text { PDK } & \text { pyruvate dehydrogenase kinase } \\ \text { PMS } & \text { pyruvate-malate shuttle } \\ \text { siRNA } & \text { small interfering RNA }\end{array}$

\section{Introduction}

In addition to the firmly established role of glycolysis in regulation of glucose-stimulated insulin secretion (GSIS), the mitochondrial component of glucose metabolism has also been implicated in pancreatic beta cell function. There are two pathways by which pyruvate can enter the mitochondrial Krebs cycle, catalysed by pyruvate carboxylase (PC) $[1,2]$ and pyruvate dehydrogenase (PDH) [3, 4]. Pyruvate is converted to the Krebs cycle intermediate oxaloacetate by PC and to acetyl-CoA by PDH [5]. In most cells the PDH pathway predominates. However, 
pancreatic beta cells produce unusually high levels of PC [6]. As a result, the beta cell is unique in that approximately equal amounts of pyruvate enter into the Krebs cycle via PC and PDH [7]. A primary role of PC in tissues such as liver and kidney is to provide a substrate for gluconeogenesis. However, as pointed out by MacDonald [8], beta cells lack the essential gluconeogenic enzyme phosphoenolpyruvate carboxykinase, and therefore the high levels of PC must be required for a different function in beta cells. $\mathrm{PC}$ is essential for anaplerosis, which is needed to maintain the Krebs cycle. Krebs cycle intermediates are depleted by many processes, including lipogenesis and synthesis of certain amino acids $[9,10]$. PC is able to restore the lost intermediates by producing oxaloacetate from pyruvate. Oxaloacetate can be converted to malate by malate dehydrogenase, then malate is released to the cytosol, where it is converted back to pyruvate by malic enzyme to form the pyruvate-malate shuttle (PMS) [1] or pyruvate cycling $[11,12]$. This shuttle requires the activity of PC and in beta cells it is capable of producing more NADPH than the pentose-phosphate shuttle [8].

A number of investigators have provided evidence that mitochondrial metabolism is coupled to insulin secretion through PC rather than PDH. Inhibition of PC with phenylacetic acid prevents GSIS [13-16]. ${ }^{13} \mathrm{C}$ nuclear magnetic resonance (NMR) isotopomer analysis [11, 12] has shown a close correlation between flux through PC and the capacity of glucose to stimulate secretion. Entry of pyruvate into the Krebs cycle via PDH does not appear to be important, since activation of PDH had only a minor effect on glucose metabolism and insulin release [17]. In addition, a recent report [18] found that a single nucleotide polymorphism in the $P C$ gene of African Americans is significantly associated with the magnitude of the acute insulin response.

Type 2 diabetes is characterised by insulin resistance and beta cell failure [19]. Once insulin resistance occurs, pancreatic beta cells must secrete more insulin to maintain normal glucose levels. Increased insulin secretion requires beta cell adaptation, a process that includes both enhanced insulin secretion and increased beta cell proliferation [20]. In type 2 diabetes, the failure of beta cell adaptation coincides with reduced activities of PC $[1,2]$ and PDH $[3,4]$. We have provided evidence that $\mathrm{PC}$ is more important to beta cell adaptation than PDH $[13,14,21,22]$. During compensated obesity, islet PDH but not PC is reduced [13, 14], indicating that normal PDH activity is not required for beta cell adaptation. In addition, the PC inhibitor phenylacetic acid reduces the beta cell proliferation response in $60 \%$ pancreatectomised rats [14] and in Zucker fatty rats [13].

Current evidence for a key role of PC in beta cell function is extensive, but is limited to correlation or is dependent on the relatively non-specific PC inhibitor phenylacetic acid. Recently more evidence was provided to support the importance of PC in beta cells $[23,24]$. In the present study, we performed specific genetic manipulation of PC activity (up- or downregulation) to produce corresponding changes in beta cell proliferation and insulin secretion; effect of PDH inhibition on insulin secretion was also tested.

\section{Methods}

Animals The principles of animal laboratory care under the guidelines of both NIH and the University of Louisville's Animal Care Committee were followed strictly. Male Sprague-Dawley rats (Taconic, Germantown, NY, USA) weighing 120 to $150 \mathrm{~g}$ were used for this research.

Cell culture Rat insulinoma INS-1 cell line was provided by G. H. Hockerman (Department of Medicinal Chemistry and Molecular Pharmacology, Purdue University, West Lafayette, IN, USA) and the cells (passages 40 to 60) were cultured as described previously [25].

Pc small interfering RNA sequence design Pc (now known as $P c x$ ) small interfering RNA (siRNA) and control sequence were designed and synthesised by Invitrogen (Carlsbad, CA, USA) (Electronic supplementary material [ESM] Table 1).

Pc siRNA transfection Pc siRNA transfection was carried out according to Stealth RNA transfection protocol (Invitrogen) and the cells were cultured for up to $72 \mathrm{~h}$.

Overexpression of $P C$ and the gene encoding pyruvate carboxylase kinase 4 in INS-1 cells Human PC cDNA was provided by the laboratory of $\mathrm{B}$. H. Robinson (Departments of Biochemistry and Paediatrics, University of Toronto, Toronto, Toronto, ON, Canada). Mouse Pdk4 cDNA was a gift from the laboratory of R. A. Harris (Departments of Biochemistry and Molecular Biology, Indiana University, Indianapolis, IN, USA). The $P C$ or $P d k 4$ gene was cloned into EcoRI site of pCDNA3 (Invitrogen) driven by cytomegalovirus promoter. Transfection of these genes into INS-1 cells was carried out according to the manufacturer's instructions for Lipofectamine 2000 (Invitrogen). Cell clones with stable PC or PDK4 overproduction were selected using G418. Control cells were treated with a vector that contained neither the $P C$ nor the $P d k 4$ gene; all other treatments were the same as for PC- or PDK4-treated cells. The experiments were carried out on an isolated clone with the highest level of overexpression of $P C$ or Pdk4.

Measurements of protein and DNA contents Protein content was assayed by a commercial kit that used BSA as standard (BioRad, Hercules, CA, USA). Cell DNA content was determined using a quantification kit (PicoGreen dsDNA; Molecular Probes, Eugene, OR, USA). 
$P C$ activity assay $\mathrm{PC}$ activity was measured according to the method of MacDonald et al. [1] using $\left[{ }^{14} \mathrm{C}\right] \mathrm{NaHCO}_{3}$ as a substrate.

Mitochondria isolation and PC protein detection Islet mitochondria isolation and detection of PC protein were measured using the method of MacDonald et al. [6] with modification [26].

Active PDH activity assay Active PDH was measured as described previously [4, 27]. Cell homogenates were used for the PDH activity assay.

$\left[{ }^{3} H\right]$ Thymidine incorporation $\left[{ }^{3} \mathrm{H}\right]$ Thymidine incorporation assay was performed by a previously described method [28]. Radioactivity in the membranes was counted by a scintillation counter (Packard Instrument, Ramsey, MN, USA).

Islet isolation and separation of islets into single cells, with subsequent Pc siRNA transfection The islets were isolated from 10-week-old male Sprague-Dawley rats by an adaptation of the Gotoh method [29]. Islets were digested with $0.25 \%$ (wt/vol.) trypsin for $5 \mathrm{~min}$ and incompletely digested islets were separated into single cells by passing through a $200 \mu$ l pipette tip. Dispersed islet cells were cultured for $1 \mathrm{~h}$ at $37^{\circ} \mathrm{C}$ in RPMI 1640 and treated with $P c$ siRNA for $48 \mathrm{~h}$ as described above.

Insulin secretion and insulin assay Insulin secretion was performed by a previously described method [21]. Insulin secreted into KRB was measured using an ELISA insulin assay kit (Linco Research, St. Charles, MO, USA).

Glucose use and oxidation Glucose use was measured by the method of Ashcroft [30]. Glucose oxidation was measured by the method of Hosokawa [31].

NADPH and $N A D P^{+}$measurement The cells or islets ( $\sim 40 \mathrm{~g}$ protein) were homogenised in $50 \mu \mathrm{l}$ of buffer

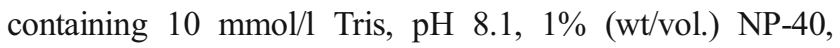
$0.5 \mathrm{mmol} / 1 \mathrm{PMSF}$ and $0.5 \%$ (wt/vol.) Triton X-100. After standing on ice for $20 \mathrm{~min}$, the homogenate was centrifuged for $2 \mathrm{~min}$ at $12,000 \times \mathrm{g}$. The supernatant fraction was combined at room temperature for $30 \mathrm{~min}$ with $5 \mu \mathrm{l}$ of $2 \mathrm{~mol} / \mathrm{l} \mathrm{NaOH}$ to destroy $\mathrm{NADP}^{+}$(for NADPH assay) or $5 \mu \mathrm{l}$ of $2 \mathrm{~mol} / 1 \mathrm{HCl}$ to destroy NADPH (for $\mathrm{NADP}^{+}$assay), after which $5 \mu \mathrm{l}$ of $2 \mathrm{~mol} / \mathrm{l} \mathrm{HCl}$ or $5 \mu \mathrm{l}$ of $2 \mathrm{~mol} / \mathrm{l} \mathrm{NaOH}$ was added to neutralise $\mathrm{pH}$ to $\sim 7$. NADPH or $\mathrm{NADP}^{+}$contents in the extract were measured by a modified method based on a cycling method described by Lowry and Passonneau [32]. Cycling reagent $(100 \mu \mathrm{l})$ containing $100 \mathrm{mmol} / \mathrm{l}$ Tris, $80 \mathrm{mmol} / 1 \mathrm{HCl}, 9 \mathrm{U} / \mathrm{ml}$ of type II glutamate dehydrogenase, $5 \mathrm{mmol} / \mathrm{l} \alpha$-ketoglutaric acid, $2 \mathrm{mmol} / \mathrm{l}$ glucose 6-phosphate,
$0.1 \mathrm{mmol} / \mathrm{l}$ ADP, $10 \mathrm{mmol} / \mathrm{l}$ ammonium acetate, $0.1 \%$ (wt/vol.) BSA and $6 \mathrm{U} / \mathrm{ml}$ glucose-6-phosphate dehydrogenase was added to each tube, and tubes were then incubated for $60 \mathrm{~min}$ at $38^{\circ} \mathrm{C}$, followed by heating to $100^{\circ} \mathrm{C}$ for $10 \mathrm{~min}$ to stop the reaction. After brief centrifugation $(500 \mathrm{~g}, 2 \mathrm{~min})$, a $100 \mu \mathrm{l}$ sample was transferred to a UV cuvette that contained $0.9 \mathrm{ml}$ reaction buffer consisting of $0.006 \mathrm{U} / \mathrm{ml}$ 6-phosphogluconate dehydrogenase, $30 \mu \mathrm{mol} / 1 \mathrm{NADP}^{+}, 0.1 \mathrm{mmol} / \mathrm{l}$ EDTA, $30 \mathrm{mmol} / \mathrm{l}$ ammonium acetate and $5 \mathrm{mmol} / \mathrm{l} \mathrm{MgCl}_{2}$ and stood at room temperature for $30 \mathrm{~min}$. The NADPH formed was measured by a fluorometer at $340 \mathrm{~nm}$ excitation and $420 \mathrm{~nm}$ emission. NADPH and $\mathrm{NADP}^{+}$standards $(0$ $10 \mathrm{nmol}$ ) were run in parallel through the entire procedure, including the extraction steps. The NADPH:NADP ${ }^{+}$ratios were calculated from the NADPH and $\mathrm{NADP}^{+}$contents measured in each assay. The blank was obtained from reaction buffer that contained islet extract, but did not contain glucose-6-phosphate dehydrogenase and glutamate dehydrogenase.

ATP, oxaloacetate and malate content measurement, and malate release from isolated mitochondria Cell extract preparation and ATP content measurement were performed using a commercial kit (Molecular Probes). Oxaloacetate and malate contents were measured from cell perchloric acid extract by the methods of Parvin et al. [33]. The method for malate release from isolated mitochondria has been previously described [22].

Data presentation and statistical methods All data are expressed as mean $\pm \mathrm{SEM}$. The listed $n$ values represent the number(s) of individual experiments performed. Comparisons between two groups were performed by Student's $t$ test. Comparisons between multiple groups were performed by one- or two-way ANOVA (Tukey's post hoc test). A value of $p<0.05$ was considered significant.

\section{Results}

PC siRNA significantly decreased PC activity and protein concentration in treated INS-1 cells We used siRNA to reduce PC protein and activity in INS-1 cells. In our preliminary tests, we compared the inhibitory effects of three pairs of siRNA on PC activity and GSIS (data not shown), selecting that with the strongest effects (ESM Table 1) for this study. As shown in Fig. 1a, siRNA significantly decreased PC activity ( $45 \%$ of control, $p<0.01)$ at $48 \mathrm{~h}$ after treatment. We chose $48 \mathrm{~h}$ of siRNA treatment because inhibition of PC activity in preliminary studies was greatest at $48 \mathrm{~h}$ (data not shown). A representative western blot (Fig. 1a) showed that content of the $130 \mathrm{kDa}$ PC protein was reduced. Quantification of the data is shown under the protein bands. The values 
a

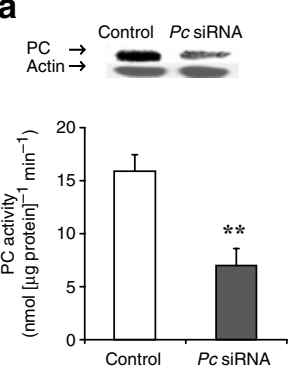

b

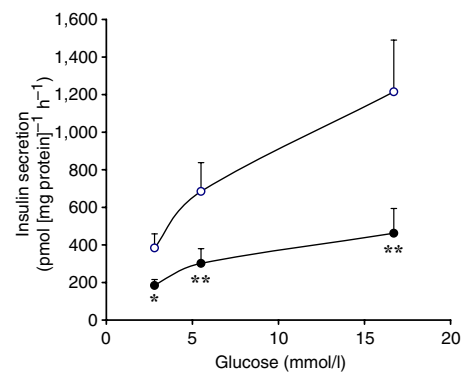

C

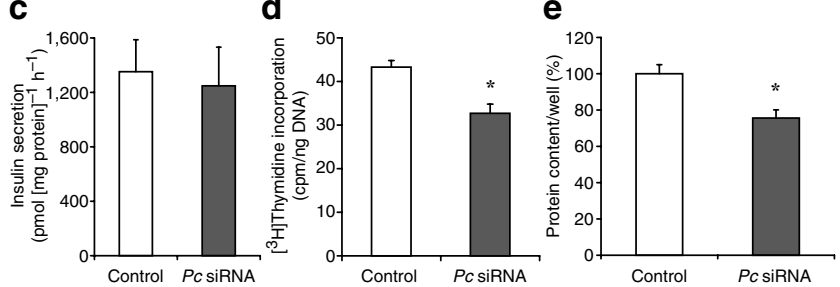

Fig. $1 P c$ siRNA decreases PC protein content, insulin secretion, cell proliferation and protein content in INS-1 cells treated for $48 \mathrm{~h}$. (a) PC protein content and activity. The representative western blot (of a total of three) shows PC protein $(\sim 130 \mathrm{kDa})$ and actin in control and $P C$ siRNA-treated cells. Protein band quantification (relative optical density) after normalisation to actin was 1.00 for control and $0.46 \pm$ $0.08(p<0.05)$ for $P c$ siRNA. White circles, control; black circles, siRNA. (b) Glucose-stimulated $(2.8,5.5$ and $16.7 \mathrm{mmol} / \mathrm{l})$ insulin secretion. (c) $\mathrm{KCl}$-stimulated $(50 \mathrm{mmol} / \mathrm{l})$ insulin secretion. (d) $\left.{ }^{3} \mathrm{H}\right]$ Thymidine incorporation. (f) Total protein content per well. Control, scrambled siRNA treatment. Data are mean \pm SEM, $n=4 .{ }^{*} p<0.05$, $* * p<0.01$ vs controls

of relative optical density (normalised to actin) were significantly reduced in the $P c$ siRNA-treated group $(p<0.05)$.

Pc siRNA significantly reduced GSIS in INS-1 cells To test whether PC regulates insulin secretion, we inhibited PC activity by treating INS-1 cells with $P c$ siRNA for $48 \mathrm{~h}$. The medium was then changed to Krebs-Ringer buffer and GSIS was performed in the presence of 2.8, 5.5 and $16.7 \mathrm{mmol} / \mathrm{l}$ glucose. Figure $1 \mathrm{~b}$ shows that $P c$ siRNA significantly downregulated the glucose dose-response curve of insulin secretion in INS-1 cells. $P c$ siRNA, however, was unable to reduce $\mathrm{KCl}$-induced insulin secretion (Fig. 1c), suggesting that the mechanism by which by $\mathrm{KCl}$ regulates insulin secretion is different from the PC pathway.

Fig. 2 Inhibition of INS-1 cell PC with siRNA treatment (48 h) did not change glucose use (a) and glucose oxidation (b), but did upregulate active PDH activity (c) in INS-1 cells. Control, scrambled siRNA. Data are the mean \pm SEM, $n=4$. $* * p<0.01$

Pc siRNA significantly suppressed DNA and protein synthesis We previously reported that changes in PC activity were associated with changes in beta cell proliferation $[13,14]$. To test whether this was a causal relationship, we measured $\left[{ }^{3} \mathrm{H}\right]$ thymidine incorporation and protein content in $P c$ siRNA-treated INS-1 cells. Figure 1d demonstrates that $\left[{ }^{3} \mathrm{H}\right]$ thymidine incorporation in INS-1 cells treated for $48 \mathrm{~h}$ with $P c$ siRNA was decreased to $78 \%$ of control $(p<0.05)$. Parallel changes were seen in cell protein content in $P c$ siRNA-treated cells (Fig. 1e). Our data demonstrate that the specific inhibition of $P c$ expression by siRNA leads to a reduction in DNA and protein synthesis, which are measures of cell proliferation.

Inhibition of PC did not reduce glucose use and oxidation in INS-1 cells We expected that inhibition of PC would lead to a reduction in glucose oxidation because about $50 \%$ of beta cell pyruvate enters the Krebs cycle by the PC pathway [7]. To test this, we measured glucose use and oxidation in INS-1 cells treated for $48 \mathrm{~h}$ with $P c$ siRNA. Surprisingly, glucose use and oxidation were not reduced (Fig. 2a, b). This result is consistent with that reported by Fransson et al. [16], who used phenylacetic acid ( $5 \mathrm{mmol} / \mathrm{l})$ to inhibit PC in isolated rat islets; their results showed that phenylacetic acid was not able to inhibit glucose oxidation. We next measured PDH activity in these INS-1 cells. PDH activity was 2.7 -fold increased ( $p<0.01$ vs control) (Fig. 2c). Interestingly, the increase in PDH did not compensate for the effect of reduced PC on GSIS and on beta cell proliferation (Fig. 1). The increase in PDH activity may be due to an increase in pyruvate concentration or a decrease in NADH:NAD ${ }^{+}$ratio and may not be associated with a change in flux; this would explain the lack of change in glucose oxidation.

Pc siRNA significantly reduced GSIS in dispersed islet cells Because INS-1 cells are a tumour cell line, we tested whether $P c$ siRNA regulates GSIS in primary beta cells. The islets isolated from male Sprague-Dawley rats were dispersed to single cells in order to improve the efficacy of siRNA treatment. Dispersed islet cells are less responsive to glucose [34], but dispersion is necessary for all cells to be exposed to the siRNA. As shown in Fig. 3a, we achieved a

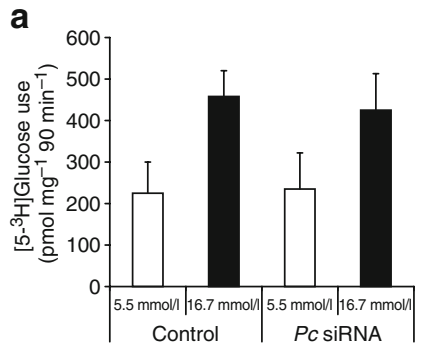

b

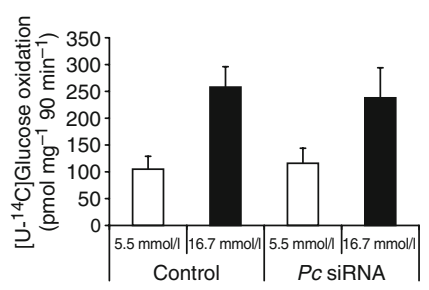

C

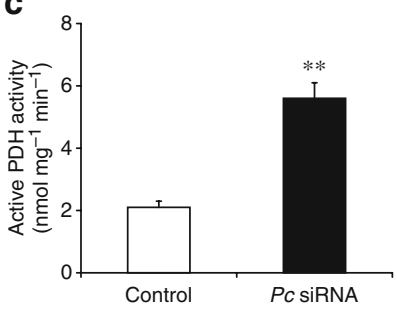


significant reduction in PC activity. Importantly, PC inhibition reduced GSIS significantly (Fig. 3b) when cells were stimulated with a high concentration of glucose $(16.7 \mathrm{mmol} / \mathrm{l})$. Figure $3 \mathrm{~b}$ shows that glucose responsiveness in control group was poor. To find out the reasons for this, we tested the effect of transfection medium on primary beta cells and INS-1 cells. Our data show that GSIS in primary beta cells was significantly suppressed by the transfection medium, but INS-1 cells were less strongly affected (data not shown); this suggests chemical toxicity from the transfection medium and vulnerability in primary beta cells.

Intermediates and products of PMS and ATP content were reduced in beta cells treated with Pc siRNA Evidence that the PMS is related to insulin secretion $[11,14]$ prompted us to measure oxaloacetate, malate contents and NADPH: $\mathrm{NADP}^{+}$ratio, since they are the intermediates or products of this shuttle. As shown in Table 1, all of these variables were significantly reduced in $P c$ siRNA-treated INS-1 cells and in dispersed islet cells. NADPH:NADP ${ }^{+}$ratios were significantly increased in response to high glucose $(16.7 \mathrm{mmol} / \mathrm{l})$ in control and siRNA-treated INS-1 cells and primary beta cells. This increase was inhibited by siRNA treatment or enhanced by $P C$ overexpression. To test shuttle activity, we measured malate release from mitochondria isolated from $P c$ siRNA-treated dispersed islet cells and INS- 1 cells. Malate release from $P c$ siRNAtreated INS-1 cells (Table 1) and from dispersed islet cells (Fig. 3c) was significantly reduced. These results confirm that PC controls flux through the PMS and that reductions in $\mathrm{PC}$ and shuttle activity coincide with reductions in insulin secretion and cell proliferation. Fransson et al. [16] have reported that $\mathrm{PC}$ is required for the fuel-induced rise in the ATP:ADP ratio. For this reason we measured ATP contents in $P c$ siRNA-treated INS-1 cells. As shown in Table $1, P c$ siRNA significantly reduced ATP contents in these cells.

Elevation of PC significantly upregulated insulin secretion and cell proliferation in stable PC overexpressing INS-1 cells Our results from $P c$ siRNA studies demonstrate that inhibition of $\mathrm{PC}$ reduced insulin secretion (Figs 1b, 3b) and cell proliferation (Fig. 1c, d). If elevation of PC leads to the opposite results, this would further support our hypothesis that $\mathrm{PC}$ has strong control in beta cell function. Therefore we overexpressed $P C$ in INS-1 cells. The clone with the highest level of $P C$ overexpression was obtained and used in present study. PC activity in this clone was increased about twofold (Fig. 4a); insulin secretion was increased 2.5fold at $2.8 \mathrm{mmol} / \mathrm{l}$ glucose and threefold at $16.7 \mathrm{mmol} / \mathrm{l}$ glucose (Fig. 4b). Basal insulin secretion was also slightly but significantly increased in other clones overexpressing $P C$ at lower levels (data not shown), suggesting that PC also controls basal insulin secretion. The stimulatory effect of $P C$ overexpression on basal insulin secretion $(2.8 \mathrm{mmol} / \mathrm{l}$ glucose $)$ (Fig. $4 \mathrm{~b}$ ) is consistent with the inhibitory effect of $P c$ siRNA on basal insulin secretion (Fig. 1b). DNA and protein synthesis was significantly increased (Fig. 4c, d). Oxaloacetate and malate contents, NADPH:NADP ${ }^{+}$ratio and malate release from mitochondria were also significantly elevated in $P C$ overexpressing INS-1 cells (Table 1). All of these results demonstrate that PC plays a key role in insulin secretion and cell proliferation.

Reduction of PDH by Pdk4 overexpression did not reduce insulin secretion PDH activity was increased in $P c$ siRNAtreated INS-1 cells (Fig. 2c). Despite the increase in PDH activity, GSIS was reduced (Fig. 1b). This indicates that the PDH pathway may not be important for insulin secretion. To further test this, we developed INS-1 cells with reduced PDH activity. This was accomplished by taking advantage of the fact that PDH activity is inactivated by PDH kinase (PDK) through phosphorylation [35]. There are four PDK isoforms in pancreatic islets $[27,36]$. We reduced PDH pathway by overproducing the PDK4 isoform in INS-1 cells. The clone with the highest level of Pdk4 overexpression was obtained and used in present study. Pdk4 overexpression in this clone produced a great reduction in PDH activity (Fig. 5a) but no significant change in PC activity (Fig. 5b). As shown in Fig. 5c, reduced PDH a

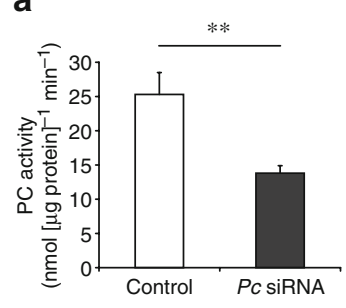

b

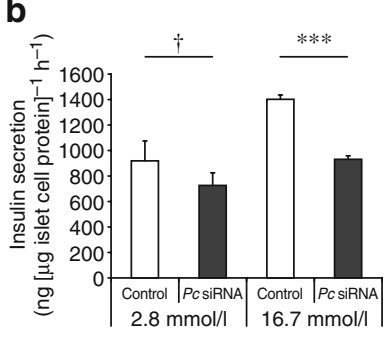

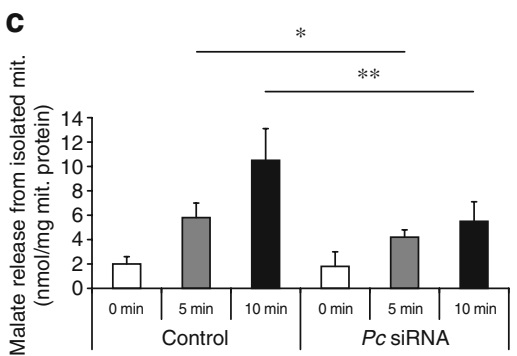

Fig. $3 P c$ siRNA treatment $(48 \mathrm{~h})$ in dispersed primary islet cells reduces PC activity (a) and leads to a reduction in glucose-stimulated $(16.7 \mathrm{mmol} / \mathrm{l})$ insulin secretion (b) and malate release from isolated mitochondria (mit.) (c). Control, scrambled siRNA. Data are the mean \pm SEM, $n=4 .{ }^{*} p<0.5,{ }^{* *} p<0.01,{ }^{* * *} p<0.001 ;{ }^{\dagger} p=0.131$ 
Table 1 Metabolite contents in INS-1 cells treated for $48 \mathrm{~h}$ with $P c$ siRNA, in dispersed Sprague-Dawley rat islet cells and in INS-1 cells overexpressing $P C$

\begin{tabular}{|c|c|c|c|c|}
\hline Cell types and variables & Control & $\mathrm{PC}$ & $N$ & $p$ values \\
\hline \multicolumn{5}{|l|}{ INS-1 cells, siRNA ${ }^{\mathrm{a}}$} \\
\hline OAA (pmol/mg cell protein) & $177 \pm 16$ & $60 \pm 14$ & 4 & $<0.001$ \\
\hline Malate (nmol/mg cell protein) & $7.8 \pm 1.9$ & $4.1 \pm 1.1$ & 4 & 0.028 \\
\hline NADPH:NADP ${ }^{+c}$ & $0.35 \pm 0.05$ & $0.26 \pm 0.07$ & 5 & 0.047 \\
\hline NADPH:NADP ${ }^{+d}$ & $0.63 \pm 0.06^{\mathrm{f}}$ & $0.36 \pm 0.13$ & 5 & 0.019 \\
\hline Malate release from mitochondria ${ }^{\mathrm{e}}$ & $12.4 \pm 2.3$ & $7.1 \pm 1.4$ & 4 & 0.013 \\
\hline ATP (pmol/mg protein) & $4.01 \pm 0.75$ & $1.78 \pm 0.27$ & 4 & 0.019 \\
\hline \multicolumn{5}{|l|}{ Dispersed rat islet cells, siRNA ${ }^{a}$} \\
\hline OAA (pmol/mg cell protein) & $85 \pm 13$ & $35 \pm 11$ & 4 & $<0.001$ \\
\hline Malate (nmol/mg cell protein) & $3.2 \pm 0.5$ & $1.8 \pm 0.2$ & 4 & $<0.001$ \\
\hline NADPH:NADP ${ }^{+} \mathrm{c}$ & $0.31 \pm 0.04$ & $0.24 \pm 0.03$ & 5 & 0.046 \\
\hline NADPH:NADP ${ }^{+}$d & $0.58 \pm 0.15^{\mathrm{f}}$ & $0.32 \pm 0.12$ & 5 & $<0.01$ \\
\hline \multicolumn{5}{|l|}{ INS-1 cells, vector expression ${ }^{\mathrm{b}}$} \\
\hline OAA (pmol/mg cell protein) & $188 \pm 19$ & $293 \pm 21$ & 4 & $<0.001$ \\
\hline Malate (nmol/mg cell protein) & $6.8 \pm 1.0$ & $11.0 \pm 1.6$ & 4 & 0.009 \\
\hline NADPH:NADP ${ }^{+\mathrm{c}}$ & $0.36 \pm 0.08$ & $0.54 \pm 0.13$ & 5 & $<0.05$ \\
\hline NADPH:NADP ${ }^{+}$d & $0.61 \pm 0.11^{\mathrm{f}}$ & $0.75 \pm 0.17^{\mathrm{f}}$ & 5 & $<0.05$ \\
\hline Malate release from mitochondria ${ }^{\mathrm{e}}$ & $13.4 \pm 1.7$ & $20.6 \pm 3.2$ & 4 & 0.012 \\
\hline
\end{tabular}

Data are mean \pm SEM

After siRNA transfection, INS-1 cells were cultivated in the culture medium with $11.1 \mathrm{mmol} / \mathrm{l}$ glucose and primary beta cells with $5.5 \mathrm{mmol} /$ 1 glucose for $48 \mathrm{~h}$. All the cells were pre-incubated in KRB containing $0.5 \%$ BSA and different concentrations of glucose for $1 \mathrm{~h}$ and then the cells were washed three times with 1x pure PBS before preparation of cell extracts. Concentrations of glucose in pre-culture medium: 11.1 mmol/ 1 (unless indicated in the table) for INS-1 cells and $5.5 \mathrm{mmol} / 1$ for dispersed islet cells

${ }^{a}$ Control refers to scrambled siRNA, PC refers to $P C$ siRNA

${ }^{\mathrm{b}}$ Control refers to control vector, PC refers to $P C$ overexpression

${ }^{\mathrm{c}}$ Pre-cultured with $5.5 \mathrm{mmol} / \mathrm{l}$ glucose for $1 \mathrm{~h}$

${ }^{\mathrm{d}}$ Pre-cultured with $16.7 \mathrm{mmol} / \mathrm{l}$ glucose for $1 \mathrm{~h}$

${ }^{\mathrm{e}}$ In nmol $10 \mathrm{~min}^{-1}$ (mg mitochondrial protein) ${ }^{-1}$

${ }_{p}^{\mathrm{f}}<0.01$ vs $5.5 \mathrm{mmol} / 1$ glucose

OAA, oxaloacetate

activity in INS-1 cells did not significantly change GSIS. Preliminary tests of glucose oxidation in INS-1 cells overexpressing Pdk4 indicated that $\left[\mathrm{U}_{-}{ }^{14} \mathrm{C}\right]$ glucose oxidation was not significantly changed (data not shown).

\section{Discussion}

Glucose metabolism regulates insulin secretion [37-39] and blockade of glucose phosphorylation [40] or glycolysis [37] inhibits insulin secretion. Of the many enzymes and intermediates needed to complete glycolysis and glucose oxidation, it is uncertain which ones play a key role in the regulation of insulin secretion. Candidate enzymes include $\mathrm{PC}$ and $\mathrm{PDH}$, which in pancreatic beta cells metabolise equal amounts of pyruvate into the Krebs cycle [7]. Previous studies [11, 12, 18], including those from our group [13, 14], suggested that PC might be important for insulin secretion and cell proliferation; however, none of those reports provided direct, causative evidence to confirm this hypothesis. In the current study, we performed the following specific genetic manipulations to test the role of PC vs PDH: (1) PC activity was decreased with siRNA in INS-1 cells and dispersed islet cells; (2) PC activity was increased by $P C$ overexpression; and (3) PDH activity was reduced by $P d k 4$ overexpression in INS-1 cells. By gene manipulation, we demonstrated that reduction or elevation of PC activity caused corresponding changes in insulin secretion and cell proliferation. In contrast, PDH inhibition did not reduce insulin secretion. The inhibition of PC production by siRNA produced a remarkable elevation in PDH activity that could substitute for impaired PC activity in order to maintain normal rates of glucose oxidation. But elevated PDH could not compensate for the affect of diminished PC to reduce insulin secretion. This means that the essential role of $\mathrm{PC}$ does not stem from maintenance of glucose oxidation, but rather from its ability to feed substrate into anaplerosis and the PMS.

The part of the current study involving siRNA inhibition of the $P c$ gene was also recently carried out by Jensen et al. [23]. Parts of their results are consistent with our findings, while other results differ markedly. Thus, similarly to our 

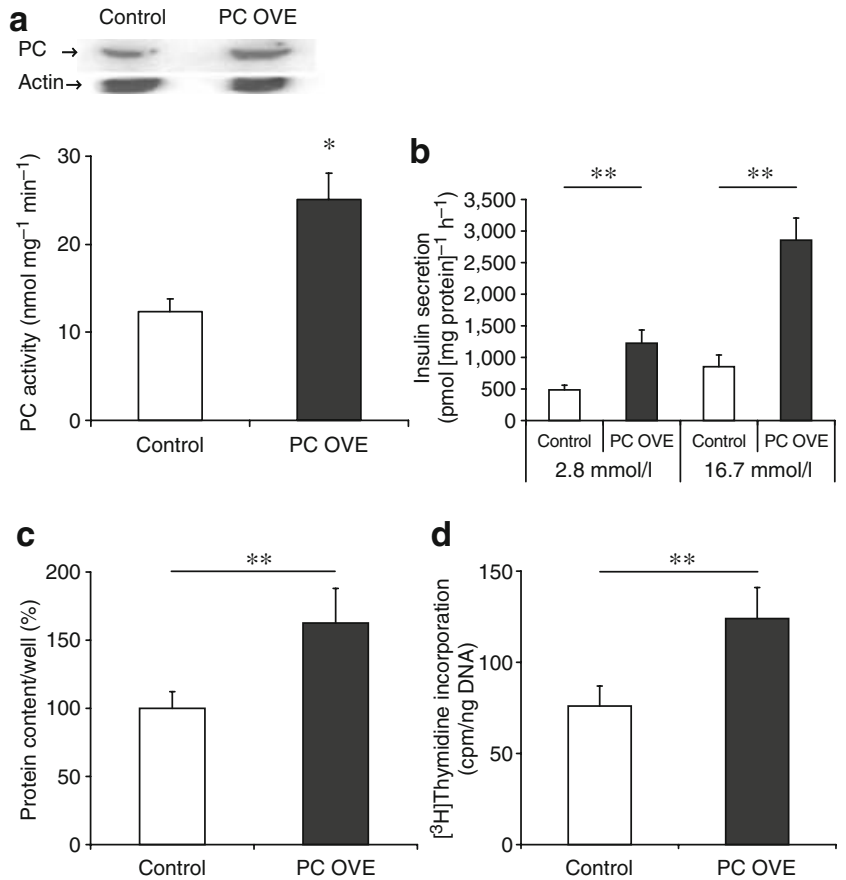

Fig. 4 Stable overproduction (OVE) of PC in INS-1 cells upregulates insulin secretion and cell proliferation. (a) PC protein content and activity, respectively. Representative western blot shows PC protein $(\sim 130 \mathrm{kDa})$ and actin (of a total of three). Protein band quantification (relative optical density) after normalisation to actin was 1.00 for control and $2.12 \pm 0.12(p<0.05)$ for PC OVE. Glucose-stimulated $(2.8$ and $16.7 \mathrm{mmol} / \mathrm{l})$ insulin secretion (b), protein content per well (c) and $\left[{ }^{3} \mathrm{H}\right]$ thymidine incorporation (d). Control cells were treated with the vector that did not contain $P C$ gene. Data are mean \pm SEM, $n=4 .{ }^{*} p<$ $0.05, * * p<0.01$ vs controls

data, Jensen et al. found that inhibition of PC $(50 \%$ downregulation of PC) had no direct affect on either glucose use or oxidation. They also found that inhibition of PC reduced PMS, measured in our studies by malate release from mitochondria and in their studies via ${ }^{13} \mathrm{C} N M R$ isotopomer analysis [23]. On the other hand, the two studies differed significantly in the effects of PC inhibition on beta cell content of NADPH or malate and on the effect of PC inhibition on insulin secretion. To explain the insulin secretion result, Jensen at al. performed radioisotopic and
${ }^{13} \mathrm{C}$-NMR-based measurements of metabolic flux and mass spectrometry-based metabolic profiling experiments; they found that an average $56 \%$ decrease in PC protein levels resulted in only about $20 \%$ reduction in flux through PC at stimulatory glucose and no significant difference in the increment of pyruvate cycling activity when glucose concentration was increased. They also found that acetylCoA and lactate levels are increased in INS-1 cells with decreased PC production, suggesting a compensatory mechanism in these cells. They also believed that PC inhibition can be compensated by pyruvate-isocitrate shuttle. These are the explanations of their insulin secretion data. In our study, however, inhibition of PC depleted both malate and NADPH. We had expected this since beta cell $\mathrm{PC}$ is a major source of malate and the malate-pyruvate shuttle is a major source of NADPH [8]. As we observed large reductions in NADPH:NADP ${ }^{+}$ratios and Krebs cycle intermediates in siRNA-treated INS-1 cells (Table 1), it is possible that this contributes to the reduction in DNA synthesis and protein content (Fig. 1c, d). In contrast to our results, Jensen et al. [23] found that PC inhibition had no effect on either malate content or NADPH.

We are confident of our findings, since we not only found that PC inhibition depleted NADPH and malate content, but also that elevation of PC produced a corresponding increase in NADPH and malate contents. The other difference in the two studies is that we found insulin secretion to be sensitive to increased or decreased PC activity, while Jensen et al. [23] saw no impact of PC inhibition on GSIS. It is possible that the differences in results are due to differences in the INS-1 cell lines used by Jensen and by us. Different strains of INS-1 cells display very different characteristics for insulin secretion [41] and PMS [11]. For example, malate content at similar glucose concentrations was more than twice as high in Jensen's cells than in our own. Also GSIS was many fold greater in Jensen's cells. These differences could have been due to higher basal levels of PC activity in Jensen's cells, which might be expected to reduce sensitivity to siRNA inhibition. However, the PC activity of Jensen's cells is not a

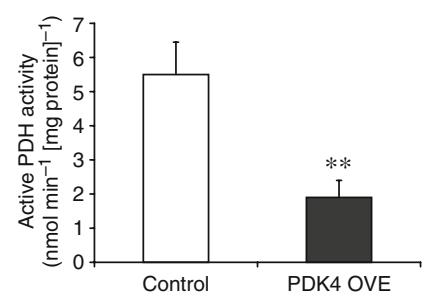

b

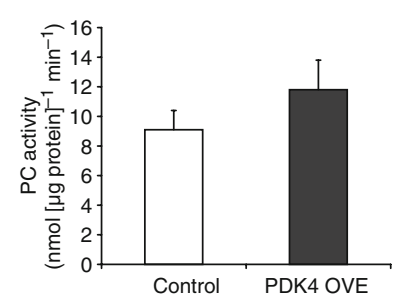

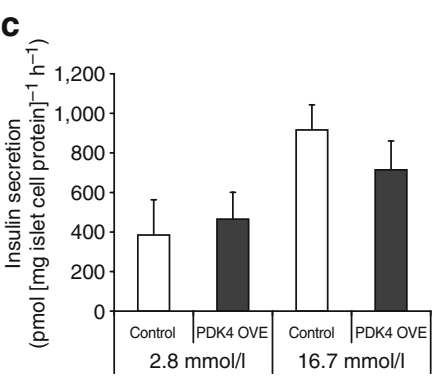

Fig. 5 Reduction of active PDH activity by overproduction (OVE) of PDK4 (a) did not significantly change PC activity (b) or glucosestimulated $(2.8$ and $16.7 \mathrm{mmol} / \mathrm{l})$ insulin secretion (c) in INS-1 cells.
Control cells were treated with the vector that did not contain the Pdk4 gene. Data are mean \pm SEM, $n=4 .{ }^{* *} p<0.01$ 
known and the reason for the different findings remains uncertain. Very recently, this group [24] provided additional evidence to support an important role of the PMS in regulation of GSIS [21]. This is consistent with our conclusion.

The importance of the PC pathway for beta cell proliferation, a response essential to the beta cell's adaptive response to insulin resistance, was demonstrated in the current study. Conversion of pyruvate to oxaloacetate, then to malate and back to pyruvate generates three important intermediates for cell proliferation: oxaloacetate, NADPH and malate. Oxaloacetate is used for protein and lipid synthesis [42-44], NADPH is needed for lipid and fatty acids synthesis [43, 44] and insulin secretion [8, 45], and malate is used for production of NADPH. Previous studies have suggested an important role for PC in beta cell proliferation. Thus we reported earlier that there is a more than a twofold increase in PC activity in islets from insulinresistant, obese Zucker rats that have a 3.9-fold [13] increase in islet beta cell mass. Cline et al. [12] also reported that an approximately fourfold increase in anaplerosis, which provides substrate for proliferation, could be attributed to an increase in PC flux in INS-1 beta cells. We found that phenylacetic acid inhibition of PC prevents the full beta cell proliferative response to $60 \%$ pancreatectomy [14]. In addition, a proliferative role for PC is not unique to the beta cell. Mutations to PC in yeast cells inhibit growth $[46,47]$, and PC activity is elevated in growing tumour cell populations [48]. The current study provides the most specific and direct evidence of PC's role in beta cell proliferation.

In summary, by manipulating PC and PDH levels, we have provided the most direct evidence that the PC pathway plays a key role in insulin secretion in dispersed islet cells and INS-1 cells, as well as in cell proliferation in INS-1 cells. Since the effects of PC were independent of total glucose metabolism and since the PDH pathway is much less important than PC, we suggest that it is the role of PC in anaplerosis and in the PMS pathway that makes it so important for insulin secretion.

Acknowledgements The preliminary data were presented at the 66th American Diabetes Association Scientific Sessions Annual Meeting, 2006, Washington, DC, USA. We thank G. H. Hockerman for providing INS-1 cell line, M. A. Carbone (Departments of Biochemistry and Paediatrics, University of Toronto, Toronto, Toronto, ON, Canada) for human $P C$ cDNA and N. H. Jeoung (Departments of Biochemistry and Molecular Biology, Indiana University, Indianapolis, IN, USA) for mouse $P d k 4$ cDNA. This work was supported by grants to Y. Q. Liu from the National Institutes of Health (P20 RR/DE17702 from the COBRE Program of the National Center for Research Resources and 1R01 DK077624-01), the American Diabetes Association (Junior Faculty Award) and by grant HL075080 to P. N. Epstein. This project was also supported by a grant (6931) from The Research Institute for Children, Children's Hospital at New Orleans.
Duality of interest The authors declare that there is no duality of interest associated with this manuscript.

\section{References}

1. Macdonald MJ, Tang J, Polonsky KS (1996) Low mitochondrial glycerol phosphate dehydrogenase and pyruvate carboxylase in pancreatic islets of Zucker diabetic fatty rats. Diabetes 45:1626-1630

2. Macdonald MJ, Efendic S, Ostenson CG (1996) Normalization by insulin treatment of low mitochondrial glycerol phosphate dehydrogenase and pyruvate carboxylase in pancreatic islets of the GK rat. Diabetes 45:886-890

3. Zhou YP, Berggren PO, Grill V (1996) A fatty acid-induced decrease in pyruvate dehydrogenase activity is an important determinant of beta-cell dysfunction in the obese diabetic $\mathrm{db} / \mathrm{db}$ mouse. Diabetes 45:580-586

4. Zhou YP, Ostenson CG, Ling ZC, Grill V (1995) Deficiency of pyruvate dehydrogenase activity in pancreatic islets of diabetic GK rats. Endocrinology 136:3546-3551

5. Wallace JC (1985) Pyruvate carboxylase. In: Keech DB, Wallace JC (eds) CRC series in enzyme biology. CRC Press, Boca Raton, pp 5-63

6. Macdonald MJ (1995) Influence of glucose on pyruvate carboxylase expression in pancreatic islets. Arch Biochem Biophys 319:128-132

7. Khan A, Ling ZC, Landau BR (1996) Quantifying the carboxylation of pyruvate in pancreatic islets. J Biol Chem 271:2539-2542

8. Macdonald MJ (1995) Feasibility of a mitochondrial pyruvate malate shuttle in pancreatic islets. Further implication of cytosolic NADPH in insulin secretion. J Biol Chem 270:20051-20058

9. Jitrapakdee S, Gong Q, Macdonald MJ, Wallace JC (1998) Regulation of rat pyruvate carboxylase gene expression by alternate promoters during development, in genetically obese rats and in insulin- secreting cells. Multiple transcripts with 5 '-end heterogeneity modulate translation. J Biol Chem 273:34422-34428

10. Jitrapakdee S, Wallace JC (1999) Structure, function and regulation of pyruvate carboxylase. Biochem J 340:1-16

11. Lu D, Mulder H, Zhao P et al (2002) 13C NMR isotopomer analysis reveals a connection between pyruvate cycling and glucosestimulated insulin secretion (GSIS). Proc Natl Acad Sci U S A 99:2708-2713

12. Cline GW, LePine RL, Papas KK, Kibbey RG, Shulman GI (2004) 13 C-NMR isotopomer analysis of anaplerotic pathways in INS-1 cells. J Biol Chem 279:44370-44375

13. Liu YQ, Jetton TL, Leahy JL (2002) Beta-cell adaptation to insulin resistance. Increased pyruvate carboxylase and malatepyruvate shuttle activity in islets of nondiabetic Zucker fatty rats. J Biol Chem 277:39163-39168

14. Liu YQ, Han J, Epstein PN, Long YS (2005) Enhanced rat betacell proliferation in $60 \%$ pancreatectomized islets by increased glucose metabolic flux through pyruvate carboxylase pathway. Am J Physiol Endocrinol Metab 288:E471-E478

15. Farfari S, Schulz V, Corkey B, Prentki M (2000) Glucoseregulated anaplerosis and cataplerosis in pancreatic beta-cells: possible implication of a pyruvate/citrate shuttle in insulin secretion. Diabetes 49:718-726

16. Fransson U, Rosengren AH, Schuit FC, Renstrom E, Mulder H (2006) Anaplerosis via pyruvate carboxylase is required for the fuel-induced rise in the ATP:ADP ratio in rat pancreatic islets. Diabetologia 49:1578-1586

17. Nicholls LI, Ainscow EK, Rutter GA (2002) Glucose-stimulated insulin secretion does not require activation of pyruvate dehydrogenase: impact of adenovirus-mediated overexpression of PDH kinase and PDH phosphate phosphatase in pancreatic islets. Biochem Biophys Res Commun 291:1081-1088 
18. Palmer ND, Langefeld CD, Campbell JK et al (2006) Genetic mapping of disposition index and acute insulin response loci on chromosome 11q: The Insulin Resistance Atherosclerosis Study (IRAS) Family Study. Diabetes 55:911-918

19. DeFronzo RA, Prato SD (1996) Insulin resistance and diabetes mellitus. J Diabetes Complicat 10:243-245

20. Leahy JL (1990) Natural history of beta-cell dysfunction in NIDDM. Diabetes Care 13:992-1010

21. Liu YQ, Moibi JA, Leahy JL (2004) Chronic high glucose lowers pyruvate dehydrogenase activity in islets through enhanced production of long chain acyl-CoA: prevention of impaired glucose oxidation by enhanced pyruvate recycling through the malate-pyruvate shuttle. J Biol Chem 279:7470-7475

22. Liu YQ, Tornheim K, Leahy JL (1999) Glucose-fatty acid cycle to inhibit glucose utilization and oxidation is not operative in fatty acid-cultured islets. Diabetes 48:1747-1753

23. Jensen MV, Joseph JW, Ilkayeva O et al (2006) Compensatory responses to pyruvate carboxylase suppression in islet beta-cells. Preservation of glucose-stimulated insulin secretion. J Biol Chem 281:22342-22351

24. Ronnebaum SM, Ilkayeva O, Burgess SC et al (2006) A pyruvate cycling pathway involving cytosolic NADP-dependent isocitrate dehydrogenase regulates glucose-stimulated insulin secretion. J Biol Chem 281:30593-30602

25. Asfari M, Janjic D, Meda P, Li G, Halban PA, Wollheim CB (1992) Establishment of 2-mercaptoethanol-dependent differentiated insulin-secreting cell lines. Endocrinology 130:167-178

26. Han J, Xu J, Epstein PN, Liu YQ (2005) Long-term effect of maternal obesity on pancreatic beta cells of offspring: reduced beta cell adaptation to high glucose and high-fat diet challenges in adult female mouse offspring. Diabetologia 48:1810-1818

27. Xu J, Han J, Epstein PN, Liu YQ (2006) Regulation of PDK mRNA by high fatty acid and glucose in pancreatic islets. Biochem Biophys Res Commun 344:827-833

28. Cozar-Castellano I, Takane KK, Bottino R, Balamurugan AN, Stewart AF (2004) Induction of beta-cell proliferation and retinoblastoma protein phosphorylation in rat and human islets using adenovirus-mediated transfer of cyclin-dependent kinase-4 and cyclin D1. Diabetes 53:149-159

29. Gotoh M, Maki T, Satomi S et al (1987) Reproducible high yield of rat islets by stationary in vitro digestion following pancreatic ductal or portal venous collagenase injection. Transplantation 43:725-730

30. Ashcroft SJ, Weerasinghe LC, Bassett JM, Randle PJ (1972) The pentose cycle and insulin release in mouse pancreatic islets. Biochem J 126:525-532

31. Hosokawa H, Corkey BE, Leahy JL (1997) Beta-cell hypersensitivity to glucose following $24-\mathrm{h}$ exposure of rat islets to fatty acids. Diabetologia 40:392-397

32. Lowry OH, Passonneau JV (1972) Enzymatic cycling. In: Lowry $\mathrm{OH}$, Passonneau JV (eds) A flexible system of enzymatic analysis. Academic Press, New York, pp 129-145

33. Parvin R, Caramancion MN, Pande SV (1980) Convenient rapid determination of picomole amounts of oxaloacetate and aspartate. Anal Biochem 104:296-299
34. Ohgawara H, Kobayashi A, Chong SJ, Akaike T, Hashimoto Y (1994) Preparation of adult pig pancreatic cells: comparative study of methods with or without proteolytic enzymes. Cell Transplant 3:325-331

35. Krutzfeldt A, Spahr R, Mertens S, Siegmund B, Piper HM (1990) Metabolism of exogenous substrates by coronary endothelial cells in culture. J Mol Cell Cardiol 22:1393-1404

36. Sugden MC, Bulmer K, Augustine D, Holness MJ (2001) Selective modification of pyruvate dehydrogenase kinase isoform expression in rat pancreatic islets elicited by starvation and activation of peroxisome proliferator-activated receptor-alpha: implications for glucose-stimulated insulin secretion. Diabetes 50:2729-2736

37. Mertz RJ, Worley JF, Spencer B, Johnson JH, Dukes ID (1996) Activation of stimulus-secretion coupling in pancreatic beta-cells by specific products of glucose metabolism. Evidence for privileged signaling by glycolysis. J Biol Chem 271:4838-4845

38. Dukes ID, McIntyre MS, Mertz RJ et al (1994) Dependence on $\mathrm{NADH}$ produced during glycolysis for beta-cell glucose signaling. J Biol Chem 269:10979-10982

39. German MS (1993) Glucose sensing in pancreatic islet beta cells: the key role of glucokinase and the glycolytic intermediates. Proc Natl Acad Sci U S A 90:1781-1785

40. Matschinsky FM (2002) Regulation of pancreatic beta-cell glucokinase: from basics to therapeutics. Diabetes 51(Suppl 3): S394-S404

41. Hohmeier HE, Mulder H, Chen G, Henkel-Rieger R, Prentki M, Newgard CB (2000) Isolation of INS-1-derived cell lines with robust ATP-sensitive $\mathrm{K}+$ channel-dependent and -independent glucose-stimulated insulin secretion. Diabetes 49:424-430

42. Menendez J, Delgado J, Gancedo C (1998) Isolation of the Pichia pastoris $\mathrm{PYC} 1$ gene encoding pyruvate carboxylase and identification of a suppressor of the pyc phenotype. Yeast 14:647-654

43. Infante JP, Huszagh VA (1998) Analysis of the putative role of 24-carbon polyunsaturated fatty acids in the biosynthesis of docosapentaenoic $(22: 5 n-6)$ and docosahexaenoic (22:6n-3) acids. FEBS Lett 431:1-6

44. Dmitriev LF (2001) Activity of key enzymes in microsomal and mitochondrial membranes depends on the redox reactions involving lipid radicals. Membr Cell Biol 14:649-662

45. Macdonald MJ (2003) Export of metabolites from pancreatic islet mitochondria as a means to study anaplerosis in insulin secretion. Metabolism 52:993-998

46. Stucka R, Dequin S, Salmon JM, Gancedo C (1991) DNA sequences in chromosomes II and VII code for pyruvate carboxylase isoenzymes in Saccharomyces cerevisiae: analysis of pyruvate carboxylase-deficient strains. Mol Gen Genet 229:307-315

47. Blazquez MA, Gamo FJ, Gancedo C (1995) A mutation affecting carbon catabolite repression suppresses growth defects in pyruvate carboxylase mutants from Saccharomyces cerevisiae. FEBS Lett 377:197-200

48. Liu KJ, Kleps R, Henderson T, Nyhus L (1991) 13C NMR study of hepatic pyruvate carboxylase activity in tumor rats. Biochem Biophys Res Commun 179:366-371 